\title{
Evaluation of the Vegetation and Proposal of Species for Rehabilitation of the Area Patrimonial "Necropolis Cristóbal Colón” in Havana, Cuba
}

\author{
Marta Marina Jiménez Águila ", Digna Velázquez Viera, Lourdes Sordo Olivera \\ Agroforestry Research Institute (INAF), Cuba
}

Copyright $(2016$ by authors, all rights reserved. Authors agree that this article remains permanently open access under the terms of the Creative Commons Attribution License 4.0 International License

\begin{abstract}
In 1987 the "Necropolis Christopher Columbus" National Monument was declared assisting to the exceptional character of its historical and artistic values. Located in roadway of Zapata and street 12 in the municipality Plaza, Havana, occupies 56 ha with 222 square, $24,5 \mathrm{Km}$ of streets and avenues and $35000 \mathrm{~m}^{2}$ of green areas. From 1990, authorities, historians, restorers and forest investigators take charge of veil, to study and to disclose their patrimonial values to maintain and to conserve the architectural beauty of monuments, gardeners and the tree-lined of the cemetery, harmonizing the specific functions of the place. The objective of the work is to evaluate the existent vegetation and to propose species to rehabilitate the patrimonial area for the duty of preserving the memory cultural citizen. The inventory, diagnosis and evaluation of the arboreal vegetation and shrubs of studied area allowed recommending species to rehabilitate the green spaces in the main artery and the sections NE, NW, SE, SW, without affecting the monuments, streets, and sidewalks. The results show up in charts, pictures, designs, outlines and arboreal cover of 2142 physical (trees and bushes) individuals was observed; prevailing the species Ficus sp.; Calophyllum antillanum Britt; Roystonea regia H.B.K. OF. Cook; Juniperus lucayana Britt. It was indicated as managing of theses spaces, particularly and generally way concluded with suggestions will contribute to elevate the cultural level and actors' management and technicians in the integral classification of the place and to enlarge the interrelation among historical institutions - cultural and environmentalists for the rehabilitation and conservation of the urban specialized landscape.
\end{abstract}

Keywords Diagnostic, Evaluation, Arboreal Vegetation, Patrimonial Values Area, City

\section{Introduction}

Two implacable thins, the time and the death, it closed in the giant cemetery "Christopher Columbus", in the city of Havana. From 130 years the polemic and the paradox between the life and the death make of Christopher Columbus Necropolis the place where maybe more daily in the entire world is mentioned to the enigmatic admiral.

During the XIX century the Havana population was affected by systematic disease that caused numerous killing, and it made insufficient capacities of burials in the General

Cemetery of Havana been founded in 1806 and known by cemetery of Espada, in honor to his founder the Bishop Juan José Diaz Espada Fernández y Landa . Office of Tourism [1]

In 1868 an epidemic of cholera morbus forced to celebrate the works of the new cemetery. The bishopric chose an extended area rectangle on near several properties located in Roadway Zapata and street 12 in the municipality Plaza, Havana .It occupies 56 ha split in 222 blocks, 24,5 Km of streets and avenues and $35000 \mathrm{~m}^{2}$ of green areas.

In 1870 the authorities of the Island summon to a competition with a view to the project of new cemetery, in this expert architects and engineers of the Havana society participate, being winning the Spanish architect Calixto de Loira y Cardoso. October $30^{\text {th }}$ of 1871 was placed the first stone, in official ceremony, as symbol of beginning of the constructions of cemetery of "Christopher Columbus", in the place that today occupies the North entrance.

The project is described like a true city with two central avenues that intersect in cross form with a Central Chapel that divides the rectangle in four areas denominated "barracks", quadrants or sections, designated by the cardinal points: Northeast (NE) Barracks; Northwest (NW) Barracks; Southeast (SE) Barracks; Southwest (SW) barracks, surrounded by a wall perimetral; Vial and tree-lined; entrance North and South, buildings North, South and General Old Osario and Central Chapel.

In 1922, a project was designed to widen the necropolis at the East. After the triumph of the Revolution in January 1 st, 1959 the existing lucrative interest were forbidden; however, the private ownership of vaults, pantheons, family chapels, as well as from the Regional Societies were respected. 
The cemetery "Christopher Columbus" is one of the impressive funeral cities of the world and considered as artistic universal values. It presents historical values among those that exponents of the architecture, the sculpture, the ornamental arts and notable's values documentaries stored in their files, at the time that testifies the Cuban identity, reasons for which it was declared in 1987 National Monument. This enclosure constitutes a place of interest for the Conservation and Patrimonial Rehabilitation of the city. Bauta [2]

Starting from 1990 a multidisciplinary team takes charge to study and promotional its values and from then on historians, restoring, investigators and forest, determine to maintain and to conserve the architectural beauty of the different monuments, the tree-lined one and the landscape in general, considering that the different types of marbles used in the works are under tropical burning sun, where a very burning atmosphere is not believed alone for the monuments but for the plants and ornamental existent trees in the place, it demands us to provide the care and appropriate maintenance to this vegetation from the anesthetic point of view, sanitarium, environmental and landscape. This interest obeys to necessity of preserving the cultural memory of the city and to the respect for the patrimony. It has allowed little by little taking conscience about the valuable character and irreversible of the works of the past.

In Cuba it is very well-known the intense program that it is carried out by the Office of Historian of the City, to reconstruct and to conserve all the places of patrimonial value in the country and in this zeal the tree-lined one is included as essential component of the urban landscape, Bauta [2].

The cemetery as open sky museum require to the conservation architectural beauty and landscape. The main problem that faces is the gradual deterioration of the tree-lined one with the rising affectation of the monumental area (Figure 1), the ignorance of the characteristics and demand of the trees used in the area and the lack of a methodology that facilitates the restoration of the landscape in the patrimonial places. Starting from this problem, the work has as objective to carry out the inventory, diagnosis and evaluation of the arboreal vegetation and existent shrub in Columbus's cemetery, Lugones et.al. [3] and propose species that contribute to the restoration of the green spaces without affectation of the monumental area that facilitate to maintain the beauty and characteristic freshness of this monument. An appropriate selection of species and use of other where their roots don't affect to the pavement and where can be carried out the prunings in the opportune moment, would help to the vegetable local atmosphere without interference in the visual of the architectural works, it is hence that the objective of this work is to evaluate the existent vegetation through a diagnosis and to propose the arboreal species and suitable shrub for the rehabilitation.

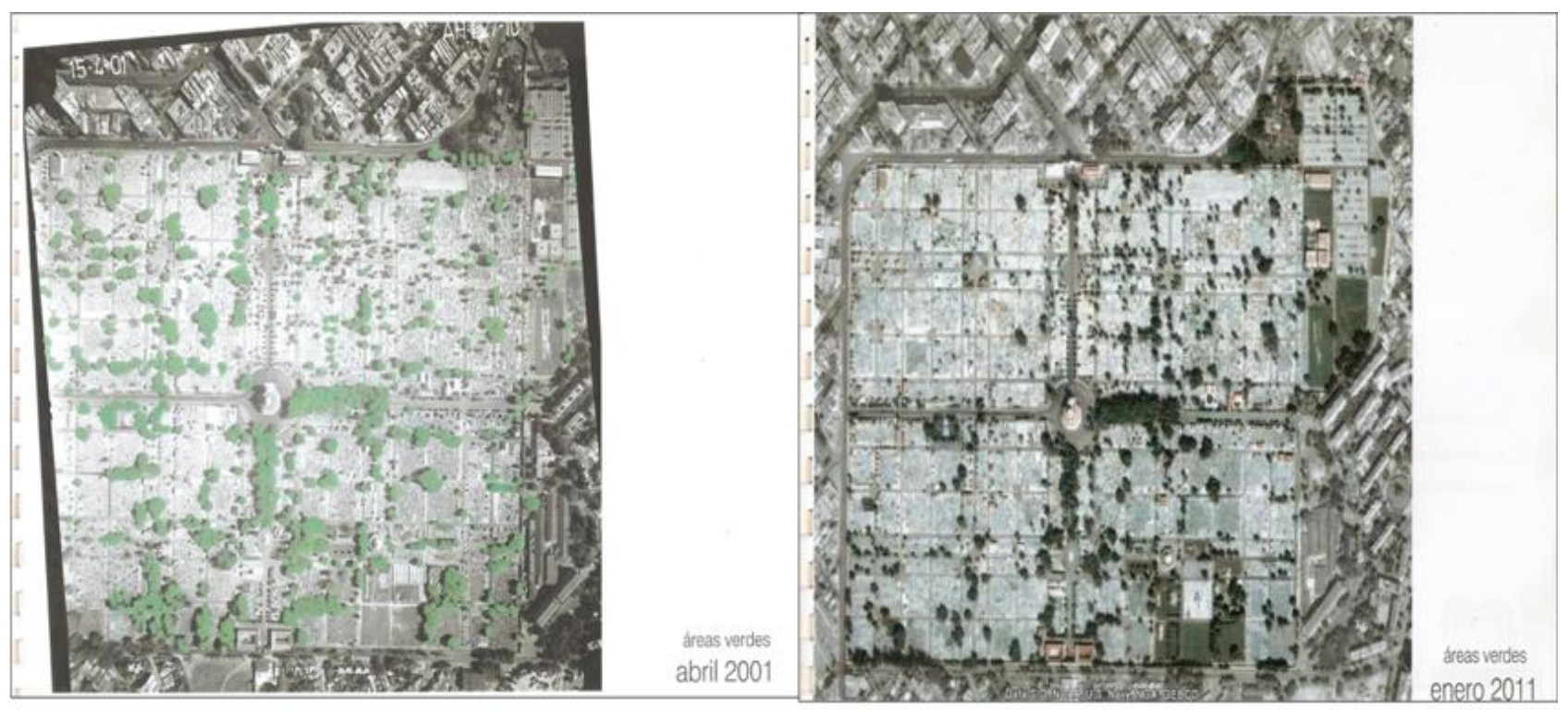

See satellite of the behavior of the vegetation. , 2001. 2011.

Figure 1. Satellite Image of Necropolis Christopher Columbus, Havana, Cuba 


\section{Materials and Methods}

The work shows detailed summarized content of two reports carried out to Columbus's cemetery in the period 2009 at the 2011 corresponding to the Phase 1 and Phase 2 Reports.

Phase 1. Main Artery of Necropolis is determined by its importance in the areas of greatest interests are: Ave Christopher Columbus from Northern Entrance (main) to the Central Chapel, Avenue Obispo Espada (from the Central Chapel to South Gate) and Avenue Fray Jacinto (from East to West Gate). These areas are identified on the map as: Monuments Zone 1st, 2nd and 3rd and middle seats.

Phase 2. Includes regard to the quadrants or "barracks" NW, NE, SW and SE, which includes streets, squares, flowerbeds and perimeter wall. These areas are identified as: Common Field, Cross of 2nd order and Expansion area.

This emblematic funeral place is located inside the city, adjacent at free traffic walker streets, housings, buildings, commercial and cultural centers, hence it requires and is indispensable the maintenance and conservation of the tree-lined one with suitable species that don't affect their social object and that contribute to the reparation and purification of the air in the urban environment.

As guide methodological that allows the arboreal classification in this area were applied Miller [4] and Carter [5] methodology adapted to the requirements and current functions of the field sacred and the following steps were considered:

\section{Office Work}

- Documentary investigation of great importance to optimize the availability of the execution time of the tasks; for this was considered the premises of each location, a base maps were consulted, as well the historical and current legal ordinances for the site.

- Study previous documentary to the field journey.

\section{Field Work}

- Traveled to study area for general characterization of each work sector, antecedents of the ordination and handling of the tree-lined one don't exist since in the place. Sketches are made and take pictures of trees.

- Inventory and Identification: existing species identification, architectural barriers, development stage and health status of the tree species, natural or mechanical deformations, and other damage with the support of the Necropolis plans; symbology of designs and colors to represent the species, status and possible solution was developed.

- Quantification of species at location: was made singular and totally, its functions, cultural attentions, and replacement or permanence.

Direct observation was used as method through the journeys carried out by the 222 blocks, 24, $5 \mathrm{Km}$. of streets and avenues and $35000 \mathrm{~m}^{2}$ of green areas. Cartographic maps and photographic camera were used. (Figures 2 and 3).

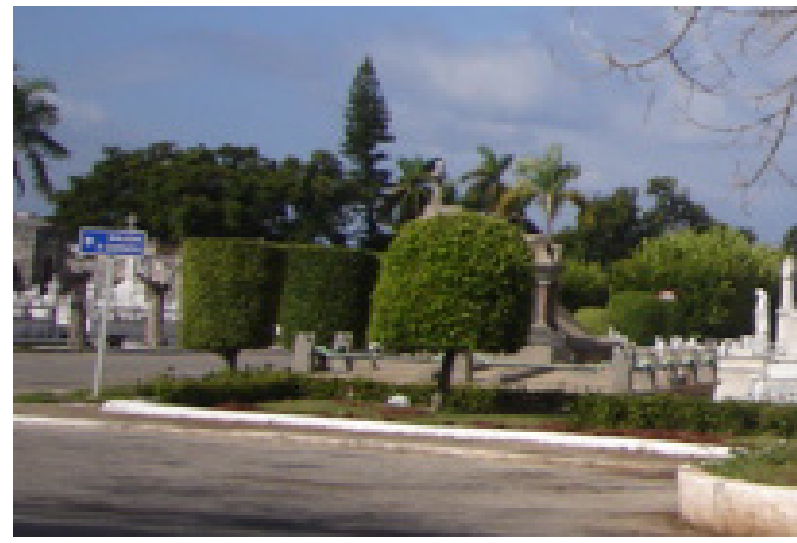

Figure 2. Columbus Necropolises, Photo: Velázquez, 2011

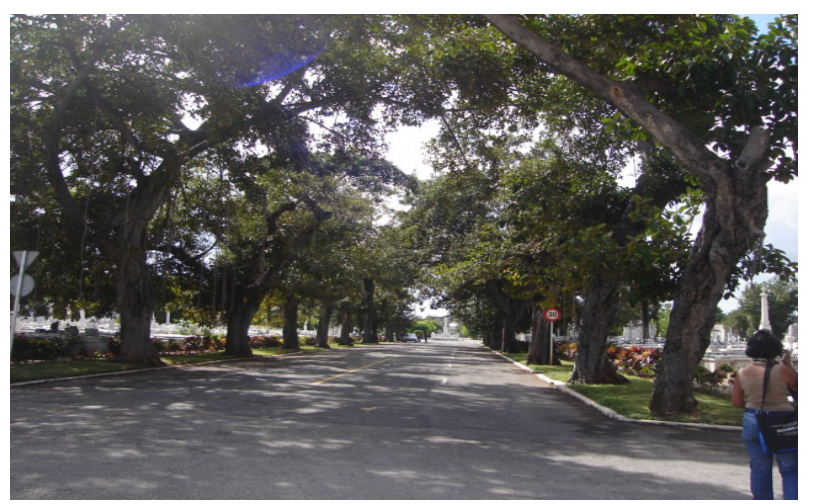

Figure 3. Inspection for inventory and diagnosis of area. Photo: Velázquez, 2011.

\section{Diagnosis, Vegetation and Evaluation, Date Processing}

For the establishment of information tables, sketches and diagrams of the different areas were made and catalogs and databases were revised for the identification taxonomic of the species (Alain [6], and [7]; Bisse [8]; Betancourt [9]). The information was processed in computer equipment and other aids.

They were carried out opened periodic exchanges with the directive to know the importance of work and to coordinate the information, approaches and new proposals in function of benefit object, as well as opinion was exchanged with workers of green and communal areas and other actors involved in the scenario study.

Finally, the validation of the proposals of changes with the technical management Patrimony Project and Local Government was conducted so that way that the results of the work were in line with the objectives and harmonious with the environment tree system is allowed according to the location of the inner city area.

\section{Results and Discussion}

Analyzing the results about the work in the Columbus's Necropolis was considered the premises of each location, the 
characterization of the sites surveyed, views of local specialists, current legal ordinances, field trips, information and documentary data use optimal and appropriate time for the inventory and diagnosis of the area. This whole process of analyzes allowed two Technical Reports: For Phase 1 "Main Artery" contains 29 pages, 11 designs, 7 tables, 24 pictures and a list of 28 species recommended.

Another one is the report of Phase 2 "Proposals for use in the four sections NW, NE, SW, and SE of Colon Cemetery" contains 42 pages, 14 designs, 6 tables with the description of 35 species. Jiménez et al. [10] and Jiménez et al. [11].

The behavior of the vegetation can be appreciated in figure 1 and figure 2, but, due to the necrological functions of the area, from the period 2001 to 2011 , this vegetation was getting lost, as well as the care of the tree-lined, alone stayed in an individual way, which caused the trees grew and it aged without control and emitted roots that have gone affecting some monuments, besides provoking invasion to niches, breaks and stains of the marbles, as showed in figures 4 and 5 .

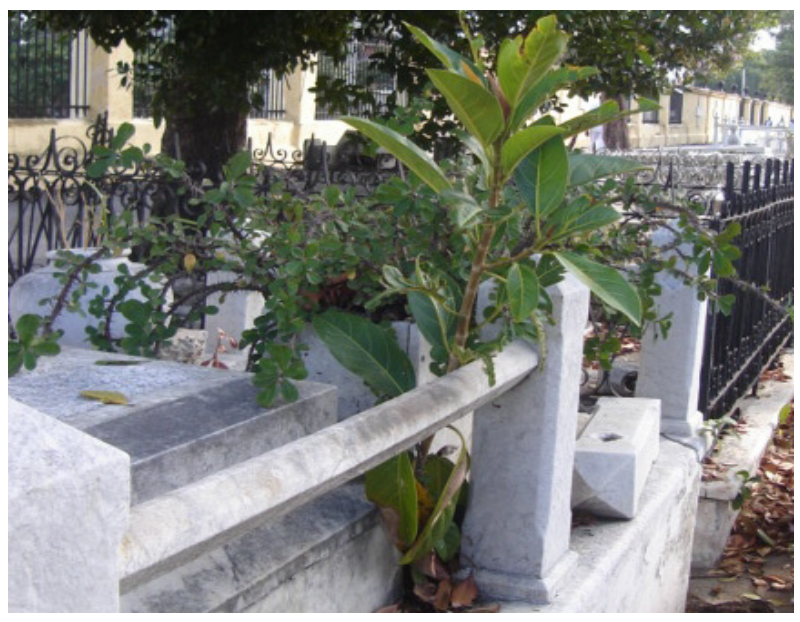

Figures 4. Problems detected in squares and monuments of the Main Artery of Columbus's Necropolis. Photo: Velázquez, 2009.

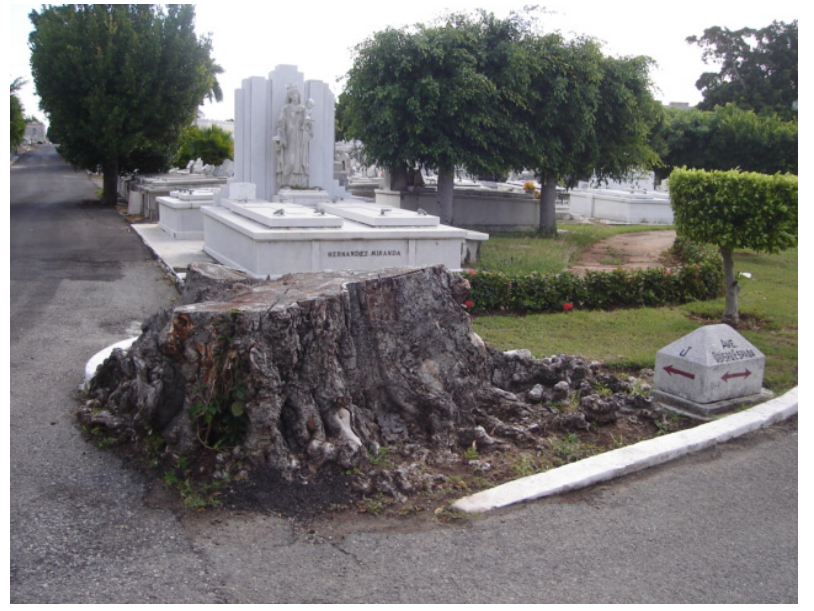

Figures 5. Problems detected in squares and monuments of the Main Artery of Columbus's Necropolis. Photo: Velázquez, 2009.

When carrying out the inventories in the journeys one could verify that little knowledge of the characteristics of trees even exists and the species used in the cemetery landscape design and with this study one could identify problems and to recommend solution and proposals. The importance of qualification was demonstrated, Jiménez [12 ]; nevertheless for this place, was not possessed a methodology or technical guide that offered orientation in order to assist and manage of different vegetation types used, without affecting the popular beliefs for the election of the species.

Columbus Cemetery, its complex function and location was important to lift the current tree, which is shown in Table 1 and Table 2; the total of existing dominant trees as well as the number of individuals proposed for rehabilitation or disposal.

Summary of distribution by species in each phase studied in the period 2009-2011, were a total of 2142 individuals of different genus and families are visualized in Columbus Cemetery, nearly at the 3000 individuals species proposed in total for this site.

Table 1. Summary of Inventory of the Tree-lined one in the Main Artery of Columbus's Cemetery, (Phase 1.) 2009 -2010.

\begin{tabular}{|c|c|c|c|c|c|}
\hline PLACE & $\begin{array}{l}\text { Nr. Trees in } \\
\text { sidewall Left }\end{array}$ & $\begin{array}{c}\text { Nr. Trees in sidewall } \\
\text { right }\end{array}$ & $\begin{array}{l}\text { Nr. Trees to be } \\
\text { eliminated }\end{array}$ & $\begin{array}{l}\text { Nr. Trees to be } \\
\text { planted. }\end{array}$ & Nr. species \\
\hline Ave Cristóbal Colon & 47 & 39 & 13 & 12 & 7 \\
\hline Capilla Central (Church) & 23 & 20 & 7 & 14 & 8 \\
\hline Ave. Espada & 42 & 35 & 5 & 6 & 4 \\
\hline Ave. Fray Jacinto East & 44 & 40 & 3 & 8 & 4 \\
\hline Ave. Fray Jacinto Western & 93 & 80 & 23 & 15 & 4 \\
\hline Subtotal & 249 & 214 & \multirow{2}{*}{51} & \multirow{2}{*}{55} & \multirow{2}{*}{11} \\
\hline TOTAL & & 63 & & & \\
\hline
\end{tabular}


Table 2. Summary of the Inventory of plants for Quadrants and areas of Columbus's Necropolis, (Phase 2). 2011.

\begin{tabular}{|c|c|c|c|c|}
\hline Quadrants & Nr. of trees & $\begin{array}{c}\text { Nr. Stump, dry plant or } \\
\text { trees to be eliminated }\end{array}$ & Nr. of trees to be planted & Nr of species \\
\hline NW & 217 & 40 & 121 & 33 \\
\hline SW & 306 & 28 & 55 & 32 \\
\hline SE & 431 & 52 & 103 & 56 \\
\hline NE & 725 & 30 & 53 & 35 \\
\hline TOTAL & 1679 & 150 & 332 & 31 \\
\hline
\end{tabular}

Table 2 shows that there is no proportion in the number of trees for quadrant. The WEST zone is relatively uninhabited (523 plants in total) $217 \mathrm{NW}$ located in the quadrant and 306 in SW, while two quadrants of EAST zone present bigger population (1156 plants) with 431 in SE and 725 in NE. In this last one quadrant in spite of having the largest number of plants, the species diversity is not abundant. CITMA [13].

The arboreal abundance is compound one for 11 botanical families and 12 genus. Of them, the species more representative are Ficus and Oaks with 39\% and 24\% respectively, likewise the genus Ficus represents 59\% of all plants in Columbus's Necropolis, this percentage most be considered to limit the increase of the same one (see table 3 ).

Table 3. Arboreal abundant species in Columbus's Necropolis, 2011

\begin{tabular}{|c|c|c|c|}
\hline \multicolumn{2}{|c|}{ Species } & \multirow{2}{*}{$\begin{array}{c}\text { Total of individuals } \\
\text { by species. }\end{array}$} \\
\hline Famíly & Name scientific & Name vulgar & $\mathbf{4 8 4}$ \\
\hline Moraceae & Ficus benjamina L & Ficus & 362 \\
\hline Clusaceae & Calophyllum antillanum Britt & Ocuje & 192 \\
\hline Bignoniaceae & Tabebuia rosea (L) Hemsl & Roble & 61 \\
\hline Palmaceae & Roystonea regia O. F. Cook & Palma & 43 \\
\hline Cupresaceae & Junisperus lucayana Britton & Sabina & 51 \\
\hline Fabaceae & Erytrina glauca Willd & Vomitel & 37 \\
\hline Boraginaceae & Cordia sebestena L. & Copey & 21 \\
\hline Clusaceae & Clusea rosea Jacq & Albizia & 15 \\
\hline Mimosaceae & Albizia lebbeck (L) Benth & Almácigo & 14 \\
\hline Burseraceae & Bursera simaruba (L) Sargent & Yagruma & 14 \\
\hline Moraceae & Cecropia peltata L. & Baria & 11 \\
\hline Boraginacea & Gerascanthus gerascanthoides (HBK) Borh & Álamo & 11 \\
\hline Moraceae & Ficus religiosa L & & 1 \\
\hline
\end{tabular}

Source: Roig et. al [14]. Botanical Dictionary of Cubans Vulgar Names

The application of recommendations emitted in each study requesting by entities of the services could diminish the expenses to short, medium and large term for concept of:

- Decrease of the frequency of plantation of trees by appropriate selection of the species.

- Successive replacement of dry plants and deteriorated by appropriate and systematic treatment.

- Decrease of the repair of sidewalks, walls and properties damaged by superficial roots by use of suitable species and of appropriate prunings.

For this reason should be considered as measures the following ones:

1. The trees located in the parterres and streets should conserve a height of clean trunk at 2 to 3 meters from the base to the first branch so that allow the visualization of the monuments and pedestrian traffics underneath its branches. (Example see Figure 6).

2. The plants in hedges and stonemasons will have a maximum height from 0,5 to 0,75 meters and should be planted at a distance among plants from 0.25 to $0,30 \mathrm{~cm}$, which will offer beauty and colorings. (E.g. Calophyllum antillanum Britt ocuje, Ixora bendhuca Roxb ixora, Codeaeum variegatu, Blume. var croton, so that will require systematic prunings.

3. In the narrowest streets, it is recommended to plant species (small trees or bushes) of little development of the trunk, crown and roots to avoid the affectations to the monuments.

4. The hedges that form the species shrubs in the central and lateral rounds will stay pruned with defined borders and will follow the routes walks perimetrals ; It should be standardized in relation to place the species and its functions (as ornamental and spectrum coloring) . 
5. All died stumps should be eliminated, sick adults and deformed trees and with mechanical damages. Also, the species of fruit-bearing (oranges, bananas, guava, etc.) can not exist, the same as the species of medicinal use to avoid their utilization for the people.

6. The trees recently fields, hedges and the gardening in general should be spring systematically, to avoid economic losses, reposition of dry plants in repeated occasions.
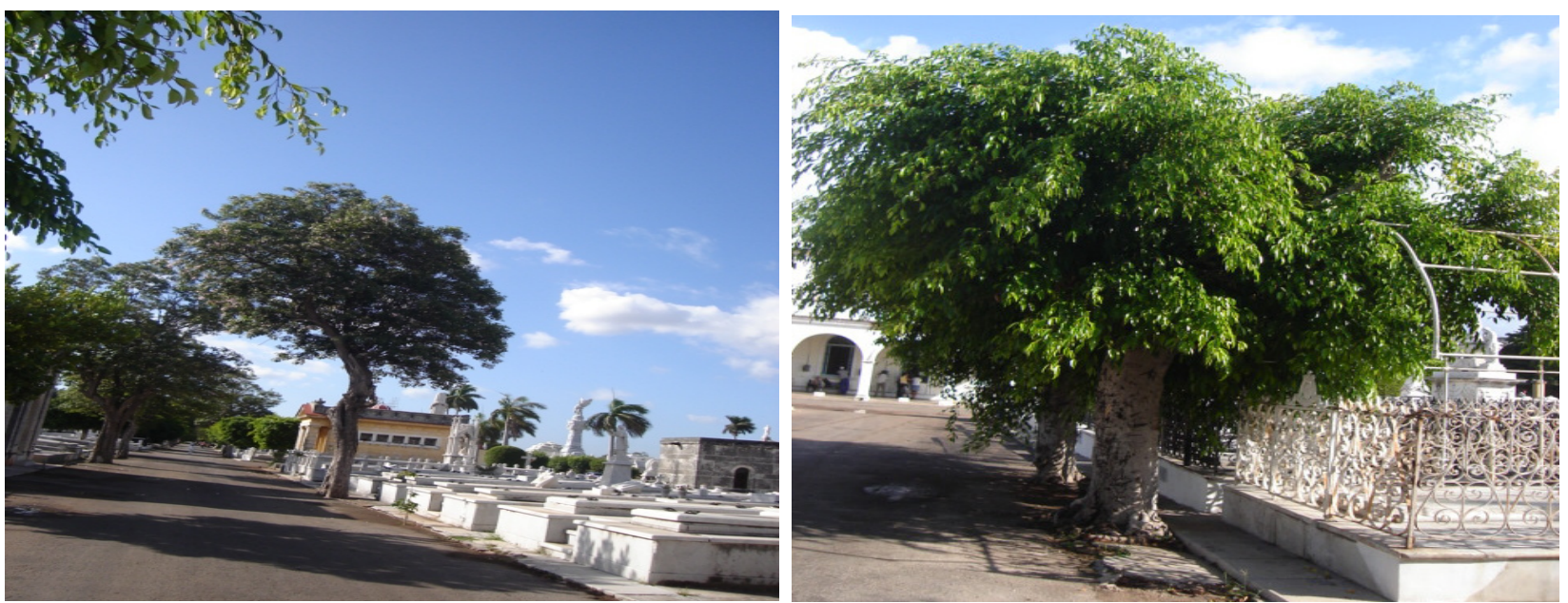

Figure 6. See of Height of the trees and visuality of Monuments
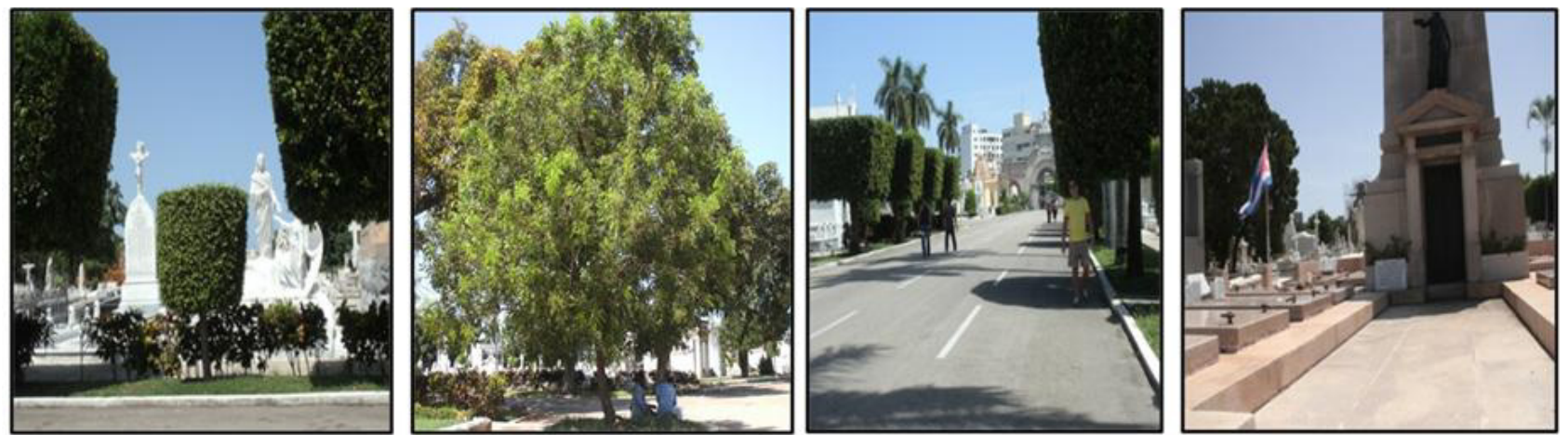

See of the arboreal rehabilitation of Columbus's Necropolis. Photo Jiménez and Velázquez, 2014.
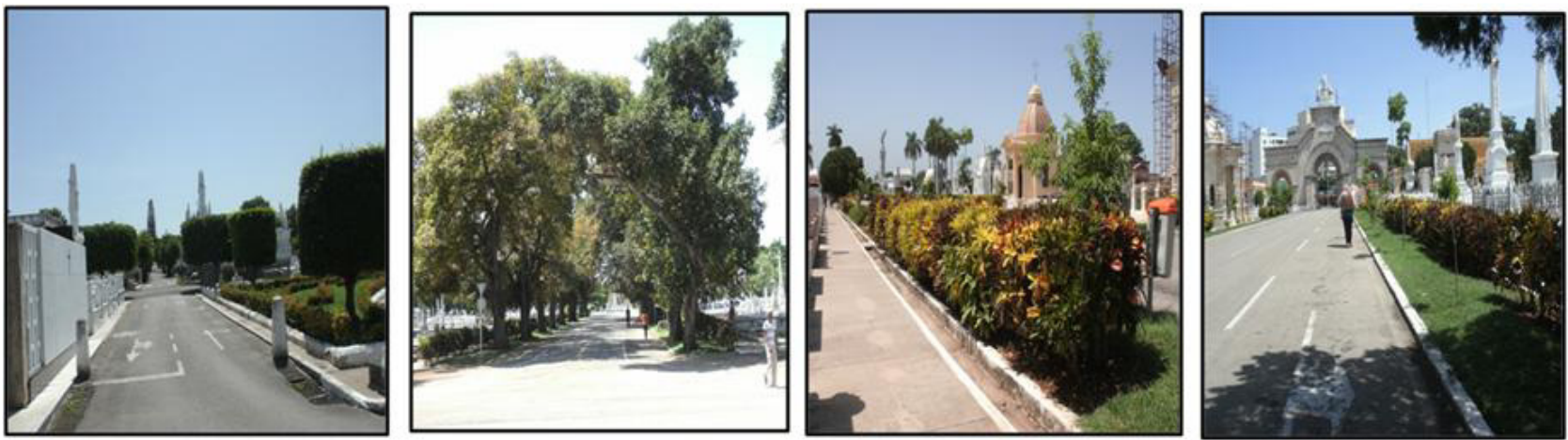

See of the rehabilitated areas of Columbus's Necropolis. Photo Jiménez and Velázquez, 2014.

Figure 7. See rehabilitation of Columbus's Necropolis. Photo: Jimenez Á. 2015. 
The results of the study contributed to increase the cultural and organizational level of the actors and manager involved in the overall planning of the site, expand the interrelationship between environmental and historical cultural institutions involved in the project of conservation and rehabilitation of the city, support the handling and management of areas with heritage values, and the actions described could enrich the existing ordinances for the rehabilitation and conservation of that urban landscape ( figure 7).

\section{Conclusions}

- The obtained results of the diagnosis indicated the existence of 11 botanical families with 12 genuses that maintained Christopher Columbus and the social functions, environmental after other species to reach the architectural beauty of the Necropolis and their relationship should require of care and systematic maintenance of the area.

- It is obtained of the study a methodological proposal that was clarified and adapted to the condition of this patrimonial place, it includes the steps to continue with the classification and the managing of the trees and this way to maintain the cultural and historical value of the place.

- The social and environmental effects is valued as positive if one keeps in mind that an urban appropriate design of the tree-lined one, impact in the beauty of the landscape and in the restitution of the energy balance serving from focus to the social activity and at the same time to the quality of the users' life and of the environmental health.

\section{REFERENCES}

[1] Office of Tourism, 2009, Necropolis "Christopher Columbus", Havana, Cuba.20 Pages.

[2] Bauta, C. 2009. The cemetery is work of the life. Interviews of Margarita Barrios. Newspaper Rebel Youth, on November, 12. 2009.
[3] Lugones Cárdenas Silva; Alexis Almaral Gaona; Juan Carlos Cabré Buggé. (S/a). Reforestation Project "Project of Landscape, Re-establishment and Forest Repopulation for Columbus's "Cemetery. Havana, Cuba.

[4] Miller R W "Urban Forestry Planning and Managing Urban Green spaces" Dpto .De Montes .FAO. Roma .Santiago de Chile. Oficina Regional para América Latina y del Caribe, 1998.

[5] Carter, E Jane. El Potencial de la Silvicultura Urbana en los Países en Desarrollo . Concepto. Dpto. de Montes. FAO. Roma. Santiago de Chile. Oficina Regional para la América Latina y del Caribe. 1996.

[6] Alain, H. 1963. Flora de Cuba. Book I V. University Editorial, University of Puerto Rico, River Stones. 13-146.

[7] Alain, H.1974. Flora de Cuba. Supplement Institute Cuban of Book. Havana. 150 pp.

[8] Bisse, J. 1988. Trees of Cuba. Scientific -Technician Edition. Havana City 384 p.

[9] Betancourt A. 2000. Exotic maderable trees in Cuba. Havana. Cuba. 352 pages.

[10] Jiménez Águila Marta M., Velázquez Viera Digna and Sordo Olivera Lourdes 2009 -2010. Phase 1. Inventory and diagnosis of the existent vegetation in the Main Artery (cross) of Columbus's Necropolis. INAF. Havana, Cuba. Technical Report. 30 pages. 2009. 2010. Scientific- Technician Service. Codec 212146

[11] Jiménez Águila Marta M., Velázquez Viera Digna and Sordo Olivera Lourdes. 2010. 2011 Phase 2. Inventory and diagnosis of the tree-lined one and existent vegetation In Quadrants NW, SW, SE and NE of Columbus's Necropolis., INAF. Havana, Cuba. Technical Report, 43 pages. Scientifictechnician Service. Codec. 212146

[12] Jiménez Águila Marta M., 2009. "Develop of the Urban Forestry in Cuba. Perspectives. "Organic Magazine Agriculture. "The forests grow". Year 15. No. 3. 2009. ISSN 1028 - 2130. P. 22 - 23.

[13] CITMA, 2009. IV National Report to the Agreement about the Biological Diversity of Cuba / CITMA. Global Project GEF /PNUD-197p.

[14] Roig and Mesa J.T, 1965. Botanical Dictionary of Cubans Vulgar Names. Havana Cuba. Tomo I and II. Publisher of the National Council of University. 